\title{
PENGARUH RASIO KEUANGAN CAMEL TERHADAP KONDISI DI BANK PERKREDITAN RAKYAT KABUPATEN TABANAN
}

\author{
Nyoman Ariyoga Nuryadiputra ${ }^{1}$ \\ ${ }^{1}$ Fakultas Ekonomi dan Bisnis Universitas Udayana (Unud), Bali - Indonesia \\ email: ariyoganp@gmail.com/Telp: +62 81703736373
}

\begin{abstract}
The research aims to analyze the probability of troubled rural bank credit conditions that are influenced by CAMEL ratio with the proxies are the ratio of CAR, NPL, PPAP, NPM, ROA, BOPO, and LDR. Population in the study is the Conventional Rural Credit Bank located in Tabanan Regency. The sample is determined by the saturated sample method, so the number of samples is 19 banks for 3 years observation from 2015 to 2017, so that 57 observations are obtained. Data analysis was carried out by logistic regression techniques with a significance level of 5\%. The results showed that the CAR, NPM, and ROA ratios had a negative effect on the probability of troubled conditions for rural banks in Tabanan Regency. Other variables such as NPL, PPAP, BOPO, and LDR have a positive effect on the probability of problematic conditions at BPR in Tabanan Regency.
\end{abstract}

Keywords: Probability; Finance ratios; CAMEL; BPR.

\begin{abstract}
ABSTRAK
Penelitian memiliki tujuan untuk menganalisis probabilitas kondisi bank perkreditan rakyat yang bermasalah yang dipengaruhi oleh rasio CAMEL dengan proksinya adalah rasio CAR, NPL, PPAP, NPM, ROA, BOPO, dan LDR. Populasi dalam penelitian merupakan Bank Perkreditan Rakyat Konvensional yang terdapat di Kabupaten Tabanan. Sampel ditentukan dengan metode sampel jenuh, sehingga jumlah sampel adalah 19 bank untuk 3 tahun pengamatan dari tahun 2015 sampai 2017, sehingga diperoleh 57 observasi. Analisis data dilakukan dengan teknik regresi logistik dengan tingkat signifikansi 5\%. Hasil penelitian memperlihatkan bahwa rasio CAR, NPM, dan ROA berpengaruh negatif terhadap probabilitas kondisi bermasalah BPR di Kabupaten Tabanan. Variabel-variabel yang lain yaitu NPL, PPAP, BOPO, dan LDR berpengaruh positif terhadap probabilitas kondisi bermasalah di BPR Kabupaten Tabanan.
\end{abstract}

Kata Kunci: Probabilitias; Rasio Keuangan; CAMEL; BPR.

\section{PENDAHULUAN}

Perekonomian Indonesia mengalami dampak yang sangat serius ketika terjadinya krisis ekonomi di tahun 1997. Dampak yang paling signifikan dirasakan oleh sektor perbankan Indonesia sebagai respon dari krisis nilai tukar yang terjadi. Seusai krisis ekonomi di tahun 1998, segala usaha mulai dilakukan oleh industri perbankan untuk bangkit dan mengembangkan kembali usaha 
perbankannya (Saiya \& Pandowo, 2015). Peningkatan kualitas pelayanan dapat memperbaiki kinerja bank dan berguna dalam menumbuhkan kembali reputasi maupun citra perbankan di mata masyrakat. Kinerja bank kemudian digunakan sebagai tolok ukur dalam menentukan tingkat kesehatan bank (Lianawati, et al., 2016). Tingkat kesehatan bank menjadi salah satu pertimbangan penting bagi para pemangku kepentingan seperti investor maupun nasabah yang akan mempercayakan dananya. Oleh karena itu, memastikan bank berada pada kondisi yang sehat merupakan hal yang penting untuk diperhatikan, sebab kepercayaan investor dan nasabah merupakan salah satu faktor yang mendukung keberlangsungan bisnis perbankan.

Bank merupakan lembaga keuangan sebagai tempat untuk menghimpun dana bagi masyarakat yang memiliki kelebihan dana, dan meminjam dana bagi masyarakat yang kekurangan. Selain itu, di dalam bank juga dapat dilakukan berbagai macam transaksi keuangan lain, seperti investasi, penyetoran maupun penarikan uang, dan transaksi keuangan lainnya. Masyarakat pedesaan umumnya mengenal Bank Perkreditan Rakyat (BPR) sebagai tempat untuk melakukan transaksi keuangan. Namun dewasa ini tidak hanya di desa, BPR bahkan telah menjamu ke perkotaan, dan cukup mampu dalam meningkatkan kelancaran permodalan masyarakat desa. Dibandingkan dengan Bank Umum, BPR melaksanakan kegiatan kerja yang lebih sederhana dalam pemberian jasa keuangan. Akan tetapi, BPR menawarkan suku bunga yang lebih tinggi dari bank umum, dan bergerak aktif dalam mengajak orang untuk bekerjasama. Kecenderungan masyarakat lebih memilih bank umum disebabkan karena 
kekurangan BPR yang tidak bisa melayani transaksi pembayaran, dan sempitnya ruang lingkup BPR yang hanya terbatas pada lingkungan sekitar operasinya.

Bank bisa mengalami kondisi bermasalah dan harus ditutup kalau kinerjanya buruk atau naiknya aset bermasalah secara signifikan. Penyebab lain adalah bank tersebut kesulitan likuiditas karena adanya penarikan dana secara besar-besaran dalam waktu bersamaan karena terjadinya krisis bersifat sistemik, bank run, maupun ketidakpercayaan masyarakat terhadap bank tersebut. Kesulitan likuiditas bisa juga terjadi akibat mismatch dari struktur pendanaan yang lebih bersifat jangka pendek. Kinerja menjadi masalah yang penting untuk mendapat perhatian, karena kinerja yang buruk dapat menjadi masalah. Profitabilitas bank biasanya diekspresikan melalui variabel internal dan eksternal. Penentu internal dapat didefinisikan sebagai faktor-faktor yang spesifik untuk masing-masing bank, sedangkan variabel eksternal meliputi faktor-faktor yang berkaitan dengan profitabilitas dengan struktur industri, dan dengan lingkungan ekonomi makro yang mempengaruhi operasi dan kinerja sistem perbankan (Jaouad \& Lahsen, 2018). Keadaan lingkungan yang berasal dari luar organisasi yang dapat mempengaruhi kinerja buruk bank contohnya adalah nasabah peminjam dana yang gagal dalam melaksanakan kewajibannya membayar kredit kepada bank, dapat menyebabkan bank mengalami kesulitan dalam melakukan perputaran dana nasabah (Zaki, et al., 2011).

Kredit macet pada BPR di Provinsi Bali terbukti mengalami peningkatan sebesar 3,06 persen dari angka 2,69 merangkak naik ke 5,75 persen yang dibuktikan oleh penelitian Armanto, (2016). Lembaga Otoritas Jasa Keuangan juga melakukan penelitian dengan hasil yang serupa bahwa Non Performing Loan 
BPR di Provinsi Bali meningkat dari tahun 2015 ke tahun 2016. Seperti yang telah dijelaskan sebelumnya bahwa kredit bermasalah merupakan salah satu faktor lingkungan luar yang dapat mengurangi kinerja bank.

Kabupaten Tabanan memiliki persentase kredit bermasalah tertinggi dibandingkan kabupaten lain. Selain itu, persentase ini juga selalu meningkat selama tiga triwulan yang didata. Data tersebut mengindikasikan bahwa masih terdapat masalah yang cukup serius pada BPR di Tabanan, yang mengalami peningkatan dari bulan januari 2016 hingga bulan September 2016. Hal ini menunjukkan kinerja BPR Kabupaten Tabanan masih kurang. Persentase kredit bermasalah pada BPR di Provinsi Bali dapat dijelaskan pada tabel 1.

Tabel 1.

Kredit Bermasalah BPR di Provinsi Bali

\begin{tabular}{lcccr}
\hline \multicolumn{5}{l}{ Non Performing Loan } \\
\hline Kabupaten & Triwulan I & Triwulan II & Triwulan III & Rata-rata \\
\hline Kab. Badung & $5.05 \%$ & $5.11 \%$ & $6.29 \%$ & $5.48 \%$ \\
\hline Kab. Bangli & $6.43 \%$ & $7.16 \%$ & $6.28 \%$ & $6.62 \%$ \\
\hline Kab. Buleleng & $2.42 \%$ & $2.28 \%$ & $2.88 \%$ & $2.53 \%$ \\
\hline Kab. Gianyar & $5.30 \%$ & $6.05 \%$ & $6.77 \%$ & $6.04 \%$ \\
\hline Kab. Jembrana & $2.41 \%$ & $3.19 \%$ & $3.84 \%$ & $3.15 \%$ \\
\hline Kab. Karangasem & $3.18 \%$ & $11.00 \%$ & $11.94 \%$ & $8.71 \%$ \\
\hline Kab. Klungkung & $6.32 \%$ & $7.77 \%$ & $8.71 \%$ & $7.60 \%$ \\
\hline Kab. Tabanan & $7.08 \%$ & $8.97 \%$ & $10.89 \%$ & $8.98 \%$ \\
\hline Kab. Denpasar & $2.92 \%$ & $3.02 \%$ & $3.85 \%$ & $3.26 \%$ \\
\hline Kab. /Kota lainya & $0.00 \%$ & $0.00 \%$ & $0.00 \%$ & $0.00 \%$ \\
\hline Sumber: Bank Indonesia & & & & \\
\hline
\end{tabular}

Sumber: Bank Indonesia, data diolah 2018

Tabel 1. menunjukkan bahwa Kabupaten Tabanan menjadi kabupaten tertinggi yang memiliki intensitas jumlah kredit BPR bermasalah di Provinsi Bali. 
Data tersebut juga menunjukkan bahwa terjadi peningkatan kredit bermasalah pada tiap triwulan dengan tingkat kenaikan yang cukup tajam. Tingginya nilai kredit macet merupakan indikator BPR di Tabanan mungkin banyak dalam kondisi bermasalah. Kenaikan kredit bermasalah pada BPR di Kabupaten Tabanan yaitu menyentuh angka 10.89 persen pada bulan september 2016, naik 5.72 persen dari bulan januari 2016 yaitu sebesar 5.17 persen.

Bank yang bermasalah paling banyak disebabkan oleh adanya risiko pendanaan dari transaksi keuangan yang terjadi dan faktor kurangnya permodalan (Hadad, et al., 2017). Kinerja bank memerlukan suatu alat untuk menjadi tolok ukur dalam menentukan sehat atau tidaknya bank tersebut. Alat yang sering digunakan untuk hal ini di Indonesia pada umumnya adalah Rasio CAMEL, yaitu gabungan dari beberapa rasio keuangan seperti Capital, Assets, Earnings, Management, dan Liquidity (Payamta \& Machfoedz, 1999). Hasil penelitian Prasetyo, (2005) contohnya menemukan bahwa rasio kecukupan modal (Capital Adequacy Ratio) memberikan pengaruh positif pada kondisi bermasalah bank. Akan tetapi hasil ini tidak sejalan dengan penelitian oleh Herdiningtyas \& Almilia, (2005) yang memperoleh hasil sebaliknya. Pengaruh Non Performing Loan (NPL) yang positif terhadap kondisi bermasalah bank ditemukan oleh Mulyaningrum, (2008). Adapula penelitian lain yang berbeda, yakni penelitian oleh Wicaksana, (2011). Rasio lainnya seperti Return on Assets (ROA) memberikan hasil pengaruh negatif pada kondisi bank oleh penelitian Herdiningtyas \& Almilia, (2005) yang justru penelitian oleh Jurnali, (2010) menunjukkan pengaruh yang positif. 
Rasio lain yang diteliti adalah Biaya Operasi terhadap Pendapatan Operasi (BOPO), dimana penelitian Martharini, (2010) menemukan pengaruh positif rasio BOPO terhadap kondisi bermasalah bank, yang berbanding terbalik dengan hasil penelitian Jurnali, (2010). Penelitian Nugroho, (2011) menganalisis pengaruh Loan to Deposite Ratio (LDR) pada kondisi bermasalah bank dan memperoleh pengaruh positif, dimana hasil tersebut tidak sejalan dengan hasil penelitian Harjanti, (2011) yang menemukan adanya pengaruh negatif Loan to Deposite Ratio (LDR) pada kondisi bermasalah bank. Hasil penelitian yang masih tidak seragam dan tidak konsisten antar variabel-variabel tersebut, menarik ketertarikan peneliti dalam meneliti pengaruh rasio CAMEL pada konsisi bermasalah BPR di Kabupaten Tabanan.

Teori struktur modal yang memfokuskan perhatian pada bagaimana rentabilitas dan likuiditas mampu mempengaruhi kecukupan modal adalah pecking order hypothesis yang dikembangkan oleh Myers, (1984). Teori pecking order umumnya menjelaskan mengapa perusahaan mungkin secara rasional membiarkan arus kas menentukan leverage. Ini menunjukkan bahwa perusahaan beralih ke dana utang di bawah tekanan kekurangan dana internal (Culata \& Gunarsih, 2012). Teori pecking order menyatakan bahwa perusahaan mengandalkan sumber-sumber internal dengan biaya asimetri informasi terendah, kemudian utang dan akhirnya ekuitas dengan biaya asimetri informasi tertinggi. Teori pecking order juga mengemukakan bahwa perusahaan kecil dengan lebih banyak peluang pertumbuhan harus mengeluarkan lebih banyak utang daripada ekuitas (Tilehnouei \& Shivaraj, 2014). Teori pecking order menekankan bahwa keputusan pendanaan yang optimal tidak mendapatkan leverage yang optimal. 
Jika ada defisit, maka kami memprioritaskan penggunaan lebih banyak utang perusahaan daripada menerbitkan saham baru (Wiagustini, et al., 2017).

Risiko merupakan dampak dari ketidakpastian lingkungan usaha yang dapat menyebabkan masalah serius bagi kelangsungan suatu bisnis. Hal yang bisa dilakukan untuk meminimalkan kemungkinan risiko yang terjadi adalah mengatur atau mengelola risiko tersebut, yang sering disebut dengan manajemen risiko. Manajemen risiko adalah bagian sentral dari manajemen strategis organisasi manapun. Ini adalah proses di mana organisasi secara sistematis mengatasi risiko yang melekat pada kegiatan mereka dengan tujuan mencapai manfaat berkelanjutan dalam setiap kegiatan dan di seluruh portofolio semua kegiatan (IRM, 2007). Biasanya, fokus dari praktik manajemen risiko di industri perbankan adalah untuk mengelola eksposur lembaga terhadap kerugian atau risiko dan untuk melindungi nilai asetnya. Secara umum bisnis perbankan dianggap sebagai bisnis yang berisiko (Tursoy, 2018).

Manajemen risiko dilakukan dengan beberapa langkah tepat untuk memperoleh pengelolaan yang sesuai. Menurut Kokobe \& Gemechu, (2016) manajemen risiko terdiri dari serangkaian langkah, yang menetapkan konteks, mengidentifikasi, menganalisis, menilai, mengobati, memantau dan mengkomunikasikan risiko, yang memungkinkan peningkatan pengambilan keputusan yang berkesinambungan. Manajemen risiko yang harus diperhatikan oleh bank menurut Sethi, et al., (2013) diantaranya adalah (1) risiko kredit, (2) risiko pasar, (3) risiko operasional, (4) risiko likuiditas, dan (5) risiko reputasi.

Bank merupakan lembaga keuangan yang menjalankan peran strategis dalam pertumbuhan ekonomi suatu negara sebagai lembaga keuangan utama dan 
prioritas melakukan mekanisme pembayaran (Sonaje \& Nerlekar, 2017). Bank Perkreditan Rakyat (BPR) memiliki beberapa transaksi keuangan yang tidak diijinkan untuk dilakukan, seperti menerima simpanan dalam bentuk giro dan ikut serta dalam kegiatan pembayaran, melaksanakan kegiatan menggunakan valuta asing, menjalankan usaha asuransi, melakukan penyertaan modal, dan melakukan usaha yang berada di luar kegiatan usaha yang diijinkan. Hal inilah yang menjadi salah satu perbedaan BPR dengan bank umum.

Laporan keuangan sangat berguna bagi perusahaan untuk mengevaluasi kebijakan yang akan diterapkan serta kebijakan yang telah diterapkan di suatu perusahaan (Lakada, et al., 2017). Rasio keuangan membandingkan dua data dalam suatu periode tertentu untuk menentukan pencapaian perusahaan. Rasio ini memungkinkan untuk menganalisis evolusi situasi keuangan suatu perusahaan (analisis tren), analisis cross-sectional dan analisis komparatif (Myšková \& Hájek, 2018). Rasio keuangan penting untuk dijadikan alat analisis dalam menentukan pertumbuhan perusahaan serta kondisi keuangan perusahaan menyeluruh. Oleh karena itu, hal utama bagi investor untuk melakukan analisis rasio demi menentukan langkah terutama dalam hal likuiditas, apakah memiliki utang lebih baik daripada melakukan investasi (Rashid, 2018). Pemimpin organisasi, investor, dan kreditor harus memahami cara menghitung rasio keuangan utama dan pentingnya mereka dalam menganalisis denyut nadi keuangan perusahaan (Ojo et al., 2015).

Bank bermasalah merupakan konsisi dimana bank tidak mampu lagi melaksanakan kewajiban maupun fungsinya sebagai lembaga keuangan, baik sebagai penghimpun dana maupun sebagai pemberi pinjaman sebagai akibat dari 
berbagai situasi yang terjadi dari dalam maupun luar organisasi. Kategori bank bermasalah ada dua, yakni bank bermasalah struktural, yaitu keadaan dimana bank sudah tidak mampu lagi menjalankan bisnisnya, dan bank bermasalah non struktural dimana keadaan bank yang memiliki masalah namun masih memiliki modal yang cukup untuk menjalankan usahanya.

Di Indonesia, alat analisis untuk mengkur tingkat kesehatan bank yang sering digunakan adalah rasio CAMEL. Tujuan dari CAMEL Model adalah untuk memberikan evaluasi yang akurat dan konsisten tentang kondisi keuangan dan operasi bank di bidang-bidang seperti modal, kualitas aset, manajemen, kemampuan menghasilkan dan likuiditas (Majumder \& Rahman, 2016). Rasio CAMEL adalah model penilaian untuk bank dan lembaga kredit non-bank yang menyelidiki dan menilai lima bidang bidang kinerja manajerial dan keuangan (Ebrahimi \& Seyedi., 2017). Rasio ini dapat mengukur dan mengembangkan peringkat-peringkat ini secara terpisah dengan mengandalkan rasio akuntansi yang akan mengukur kesehatan keuangan bank, sesuai dengan pengukuran kecukupan modal, kualitas aset, kualitas atau efisiensi manajemen, pendapatan, likuiditas, dan sensitivitas terhadap risiko pasar (Rahmania \& Hermanto, 2014).

Kecukupan modal merupakan aspek pertama dalam rasio CAMEL yang menunjukkan kemampuan modal yang dimiliki bank untuk mengatasi penurunan aktiva. Rasio kecukupan modal menggunakan rasio Capital Adequacy Ratio (CAR) yang menunjukkan seberapa kemungkinan aset bank dapat diatasi dengan ekuitas yang dimiliki. Aspek selanjutnya merupakan kualitas aset yang menunjukkan kemampuan bank untuk mengelola asetnya dan untuk meminimalkan masalah, jatuh tempo, atau pinjaman terjadwal ulang (Khoury \& 
Salem, 2018). Aspek ini diproksikan melalui rasio Non Performing Loan (NPL) yakni kredit macet yang dapat dimasukkan dalam total aktiva, serta rasio penyisihan penghapusan aktiva produktif.

Aspek kualitas manajemen menunjukkan tindakan evaluasi dan kontrol yang dilakukan manajer untuk mencegah dan menghadapi permasalahan dalam organisasi perbankan yang diproksikan dengan Net Profit Margin (NPM). Efisiensi manajemen mendorong sistem manajemen merespons dengan cepat terhadap lingkungan yang dinamis dan berubah (Rahman \& Islam, 2017). Rentabilitas diukur dengan 2 rasio yakni Return on Assets (ROA), dan Rasio Biaya Operasi dibandingkan dengan Pendapatan Operasi (BOPO). Kualitas pendapatan mewakili keberlanjutan dan pertumbuhan pendapatan di masa depan, nilai kesesuaian bank dan kompetensinya untuk mempertahankan kualitas dan menghasilkan secara konsisten. Likuiditas dinilai dengan melihat apakah bank mampu membayar kewajibannya kepada para pemilik dana, dan memberikan pinjaman saat dibutuhkan. Rasio ini dinilai dengan Loan to Deposit Ratio (LDR) yang ditentukan dengan membandingkan kredit yang diberikan kepada para peminjam pada dana yang dimiliki oleh pihak ketiga (Herdiningtyas \& Almilia, 2005).

Teori probabilitas menyatakan kemungkinan suatu kejadian atau peristiwa akan terjadi di masa mendatang. Probabilitas kondisi bermasalah bank menyatakan kemungkinan terjadinya kondisi bank yang bermasalah di masa mendatang. Kemungkinan tersebut dapat dilihat melalui rasio keuangan pada laporan keuangan suatu bank. Rasio kecukupan modal menunjukkan apakah bank memiliki modal yang cukup untuk melakukan operasional dan menjalankan 
kewajibannya sebagai penghimpun dan memberikan pinjaman dana kepada pihak yang membutuhkan, yang dapat dinilai dengan rasio CAR. Herdiningtyas \& Almilia, (2005) memperoleh hasil bahwa rasio CAR yang tingi memperkecil kemungkinan bank mengalami kondisi bermasalah. Apabila manajer bank mampu mengelola permodalan dengan baik, seperti menggunakan modal sendiri secara optimal, eori dan riset terdahulu maka seluruh keuntungan bank akan menjadi profit perusahaan dan tidak untuk membayar modal dari luar. Maka dari itu, hipotesis pertama dirumuskan sebagai berikut.

$\mathrm{H}_{1}$ : CAR berpengaruh negatif pada probabilitas kondisi bermasalah BPR.

Teori pecking order menyatakan bahwa perusahaan yang berukuran kecil akan lebih baik jika mengeluarkan lebih banyak utang daripada ekuitas. Hal ini menunjukkan bahwa BPR akan lebih baik apabila mampu memberikan pinjaman kepada nasabah daripada harus mengeluarkan ekuitas mereka untuk pendanaan atau investasi tertentu. Keuntungan terbesar bank adalah berasal dari kredit yang diberikan kepada peminjam. Namun, ketika peminjam tidak mampu mengembalikan dana yang dipinjam pada saat tanggal jatuh tempo, maka dampaknya adalah bank tidak menerima keuntungan. Apabila keadaan semacam ini berlangsung dalam waktu lama dan dalam skala nasabah peminjam yang besar, maka dapat dipastikan kesehatan bank akan memburuk (Ismawati \& Istria, 2015). Rasio ini jga dapat digunakan untuk menilai kemungkinan kondisi bank di masa mendatang. Besarnya nilai Non Performing Loan (NPL) menunjukkan bahwa bank memiliki dana yang tidak dapat tertagih pada nasabah, yang memungkinkan bank mengalami kekurangan dana untuk melanjutkan operasionalnya, karena bank harus mencadangkan dana yang cukup besar untuk menutupi kredit macet 
tersebut. Tingginya utang yang tak tertagih dalam Non Performing Loan (NPL), mengakibatkan bank tidak memperoleh keuntungan dari pemberian kredit. Berdasar pada pernyataan tersebut maka hipotesis kedua dirumuskan sebagai berikut.

$\mathrm{H}_{2}$ : NPL berpengaruh positif pada probabilitas kondisi bermasalah BPR.

Sama halnya dengan rasio NPL, rasio PPAP menunjukkan cukup atau tidaknya penyisihan penghapusan aktiva produktif terhadap kesluruhan total aktiva. Rasio PPAP menunjukkan bank menyisihkan dana untuk menutupi kemungkinan kredit macet peminjam. Besarnya dana dalam PPAP mengindikasikan bahwa bank memiliki keraguan pada cukup banyak kredit, sehingga hal ini berarti bahwa bank dalam kondisi yang kurang baik. Besarnya rasio ini menunjukkan bahwa terdapat sinyal bank mengalami kondisi yang kurang menguntungkan bahkan cenderung bermasalah. Pernyataan ini sesuai dengan hasil penelitian Herdiningtyas \& Almilia, (2005) bahwa rasio PPAP yang tinggi menunjukkan bank sedang dalam keadaan yang bermasalah. Hipotesis ketiga dalam penelitian ini adalah.

$\mathrm{H}_{3}$ : Rasio PPAP berpengaruh positif pada probabilitas kondisi bermasalah BPR.

Rasio NPM menunjukkan nilai laba bersih yang diperoleh dari penjualan. Tingginya rasio ini mengindikasikan bahwa perusahaan melakukan kegiatan bisnis dengan baik dan keberhasilan manajemen dalam mengelola perusahaan. Laba bersih yang tinggi menunjukkan bank dalam kondisi baik dan sehat, serta memberikan keuntungan yang lebih banyak kepada investor. Penelitian oleh Sugiyanto, (2002) memperoleh hasil bahwa manajemen mampu mengurang kemungkinan kondisi terpuruk yang dapat dialami bank. Tingginya laba ataupun 
profit yang diperoleh bank dapat menjadi sinyal bahwa bank dalam keadaan sehat dan baik-baik saja, karena memiliki keuntungan atas operasionalnya. Berdasarkan hal tersebut hipotesis keempat adalah sebagai berikut.

$\mathrm{H}_{4}$ : NPM berpengaruh negatif pada probabilitas kondisi bermasalah BPR.

Rasio ROA memberikan sinyal bahwa bank memiliki kemampuan untuk menghasilkan keuntungan atas operasional yang dijalankan dalam mengelola aset dan usaha perbankan lainnya. Nilai ROA yang tinggi mengisyaratkan bahwa operasional bank berjalan dengan lancar yang dibuktikan dengan efektivitas bank dalam mengelola asetnya (Herdiningtyas \& Almilia, 2005). Penelitian oleh Wicaksana, (2011) mendukung pernyataan tersebut, yakni menemukan bahwa ROA berpengaruh negatif pada kondisi bermasalah bank. Berdasarkan hasil penelitian tersebut, maka dapat diajukan hipotesis sebagai berikut.

$\mathrm{H}_{5}$ : ROA berpengaruh negatif pada probabilitas kondisi bermasalah BPR.

Rasio BOPO memberikan informasi mengenai tingkat laba maupun kerugian yang diperoleh bank atas kegiatan operasinya, karena memberikan perbandingan antara biaya dengan pendapatan bank. Tingginya nilai rasio BOPO memberikan petunjuk bahwa bank banyak menghabiskan biaya dalam operasional dibandingkan dengan pemasukan yang diperoleh. Hal ini juga menjadi petunjuk bahwa manajemen bank tidak mampu meminimalkan biaya operasional yang timbul, sehingga tingginya biaya akan berdampak pada menurunkan laba yang diperoleh. Penelitian yang menyatakan rasio BOPO memberikan pengaruh positif pada financial distress perusahaan perbankan dilakukan oleh Sofiasani \& Gautama, (2016). Nugroho, (2011) memperoleh hasil dalam penelitiannya bahwa 
BOPO memberikan pengaruh positif pada kondisi bank yang bermasalah, sehingga dapat dirumuskan hipotesis keenam.

$\mathrm{H}_{6}$ : BOPO berpengaruh positif pada probabilitas kondisi bermasalah BPR.

Rasio LDR membantu dalam menganalisis kemampuan bank dalam menjalankan operasionalnya seperti memberikan pinjaman dan memberikan return pada pemilik dana. Sesuai dengan teori pecking order, perusahaan yang masih dalam skala kecil seperti BPR yang umumnya beroperasi dalam lingkup pedesaan akan lebih baik untuk memberikan pinjaman lebih banyak kepada nasabah daripada menggunakan ekuitas, namun apabila hal ini tidak dibarengi dengan tingkat pengembalian yang sesuai tanggal jatuh tempo oleh nasbaha juga dapat menyebabkan bank berada pada kondisi bermasalah. Tingginya rasio LDR memberikan petunjuk bahwa bank mengalami kesulitan dalam menjalankan apa yang menjadi kewajibannya. Jurnali, (2010) dalam penelitiannya menemukan bahwa rasio ini memberikan dorongan atau pengaruh yang kuat pada kemungkinan kondisi bermasalah BPR, maka dari itu hipotesis yang dikembangkan adalah.

$\mathrm{H}_{7}$ : LDR berpengaruh positif pada probabilitas kondisi bermasalah BPR.

\section{METODE PENELITIAN}

Penelitian dilakukan dengan metode kuantitatif yang berdasarkan atas fakta untuk menguji sampel penelitian. Rasio CAMEL dalam penelitian ini digunakan untuk mengetahui pengaruhnya atas kondisi yang dialami Bank Perkreditan Rakyat. Penelitian mengambil lokasi pada BPR konvensional di Kabupaten Tabanan, dengan alasan bahwa kondisi BPR Kabupaten Tabanan cukup 
bermasalah melihat persentase kredit macet yang mencapai angka sangat tinggi dari yang dapat ditoleransi Bank Indonesia pada tahun 2016. Populasi dalam penelitian ini adalah BPR sesuai dengan batasan yang telah ditetapkan dalam UU No. 7 tahun 1992 tentang Perbankan sebagaimana diubah dengan UU No.10 tahun 1998 yaitu bank yang melaksanakan kegiatan usaha secara konvensional dan/atau berdasarkan prinsip syariah yang dalam kegiatannya tidak memberikan jasa dalam lalu lintas pembayaran. Populasi yang menjadi jangkauan penelitian ini adalah BPR yang berada di wilayah Kabupaten Tabanan.

Sampel ditentukan dengan metode sampel jenuh, dimana sampel terbagi menjadi 2 kategori bank, yakni bank yang tidak bermasalah dan bank yang bermasalah. Bank yang menjadi sampel dalam penelitian ini diantaranya PT. PR Sari Dananiaga, PT. BPR Kertha Warga, PT. BPR Amertha Sari, PT. BPR Penebel, PT. BPR Sedana Murti, PT. BPR Sedana Yasa, PT. BPR Karunia Dewata, PT. BPR Ayunulus, PT. BPR Bunga Sutra Mas, PT. BPR. Restu Dewata, PT. BPR Artha Adyamurthi, PT. BPR Sewu Bali, PT. BPR Prisma Bali, PT. BPR Bumi Prima Dana, PT. BPR Dharmawarga Utama, PT. BPR Jero Anom, PT. BPR Luhur Damai, PT. BPR Dewata Indobank, dan PT. BPR Artha Budaya.

Teknik analisis data dalam penelitian ini adalah regresi logistik dengan menggunakan variabel dummy. Daam variabel dummy yang digunakan, nilai 1 sebagai tanda bank yang memiliki masalah, dan nilai 0 sebagai tanda bank yang sehat dan tidak bermasalah. Ghozali, (2002) merumuskan formula dari regresi logistik sebagai berikut.

$\mathbf{Y}=\operatorname{Ln} \frac{p}{1-p}=b 0+b 1 C A R+b 2 N P L+b 3 P P A P+b 4 N P M+b 5 R O A+b 6 B O P O+$ b7LDR + e

Dimana: 


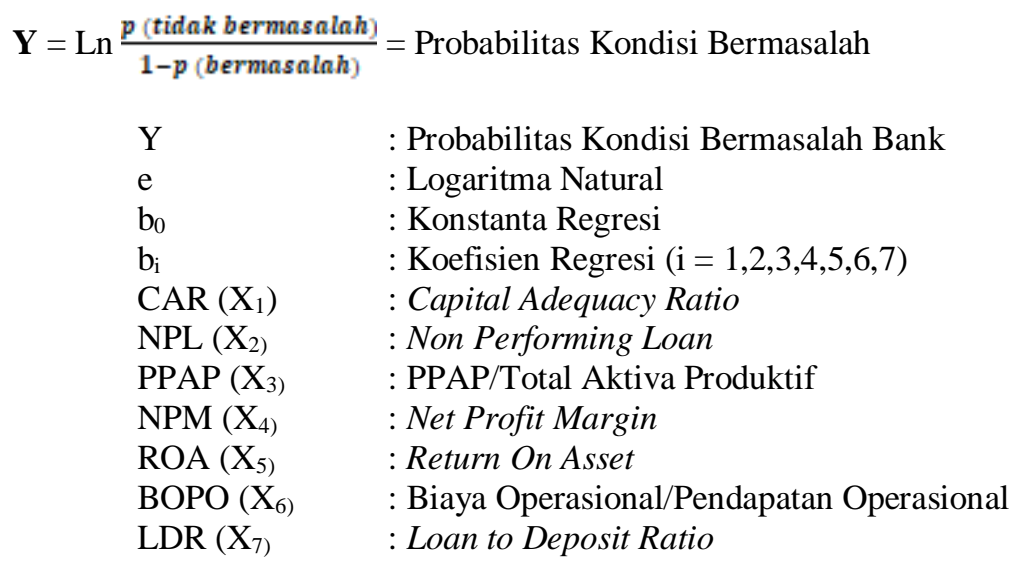

\section{HASIL DAN PEMBAHASAN}

Penelitian dilakukan pada laporan keuangan BPR Kabupaten Tabanan yang berjumlah 19 bank pada 3 tahun berturut-turut yakni periode 2015 sampai 2017, sehingga total sampel secara keseluruhan sebanyak 57 bank sampel. Tabel 3 . menunjukkan probabilitas kondisi bank.

Tabel 3.

\section{Probabilitas Kondisi Bermasalah}

\begin{tabular}{llrrrr}
\hline & & Frequency & Percent & $\begin{array}{c}\text { Valid } \\
\text { Percent }\end{array}$ & $\begin{array}{c}\text { Cumulative } \\
\text { Percent }\end{array}$ \\
\hline \multirow{3}{*}{ Valid } & $\begin{array}{l}\text { tidak } \\
\text { bermasalah }\end{array}$ & 50 & 87.7 & 87.7 & 87.7 \\
& Bermasalah & 7 & 12.3 & 12.3 & 100.0 \\
& Total & 57 & 100.0 & 100.0 & \\
\hline Sumber: & & & &
\end{tabular}

Tabel 3. memperlihatkan bahwa jumlah bank yang tidak bermasalah mendominasi yaitu sebanyak 50 bank dengan persentase 87,7 persen, sedangkan sisanya sebanyak 7 bank dikategorikan sebagai bank yang bermasalah dengan persentase sebesar 12,3 persen.

Statistik deskriptif bertujuan untuk memberikan gambaran mengenai data penelitian baik dari segi nilai minimum dan maksimum, rata-rata, serta standar deviasi masing-masing variabel. Hasil pengujian statistik deskriptif disajikan dalam tabel 4. 
Tabel 4.

Hasil Statistik Deskriptif

\begin{tabular}{lrrrrr}
\hline & N & Minimum & Maximum & Mean & Std. Deviation \\
\hline CAR & 57 & 2.30 & 62.00 & 23.1318 & 12.21608 \\
NPL & 57 & .00 & 57.00 & 11.8596 & 10.37414 \\
PPAP & 57 & 5.00 & 288.16 & 95.3887 & 35.36443 \\
NPM & 57 & -514.30 & 45.40 & -3.4378 & 95.83758 \\
ROA & 57 & -53.00 & 8.00 & 1.2632 & 9.18952 \\
BOPO & 57 & 49.00 & 570.00 & 100.7719 & 74.47987 \\
LDR & 57 & 56.00 & 98.00 & 82.0702 & 9.98009 \\
Probabilitas & & & & & .33113 \\
Kondisi & 57 & .00 & 1.00 & & \\
Bermasalah & & & & & \\
$\quad$ Valid N & 57 & & & & \\
$\quad$ (listwise) & & & & &
\end{tabular}

Rasio CAR dengan nilai minimum 2,30 diperoleh dari BPR Sedana Yasa tahun 2017 berarti kondisi bank kurang baik karena kurangnya kemampuan bank menutupi penurunan aktiva, sebab berada di bawah batas dari Ban Indonesia sebesar 8 persen. Nilai maksimum 62,00 diperoleh BPR Restu Dewata tahun 2016, mencerminkan bank memiliki kemampuan yang baik dalam menghadapi risiko kerugian. Rasio NPL yang memiliki nilai minimun 0,00 dari BPR Prisma Dana tahun 2015 berarti bahwa bank tidak dapat memberikan kredit kepada nasabah, sedangkan nilai maksimum 57,00 dari BPR Bunga Sutra Mas tahun 2017 menunjukkan bahwa terdapat 57 persen kredit yang masih berada dalam kondisi bermasalah. Nilai minimum rasio PPAP 5,00 dari BPR Karunia Dewata tahun 2016 menunjukkan kemampuan manajemen bank dalam menjaga aktiva produktif. Semakin besar nilai PPAP maka semakin buruk aktiva produktif bank tersebut yang juga diperoleh oleh BPR Karunia Dewata tahun 2017 sebesar 288, 16. 
Nilai minimum NPM menunjukan angka negatif dari BPR Ayunulus tahun 2017 berarti manajemen bank masih memiliki kekurangan atau belum optimal dalam mengelola aset untuk memperoleh laba yang lebih tinggi, karena berada dibawah standar yang ditetapkan Bank Indonesia yaiut 0,5\%. Sedangkan nilai maksimum sebesar 45,40 dari BPR Amerta Sari tahun 2016 menunjukkan manajemen melakukan pengelolaan biaya-biaya dengan baik. Nilai minimum dari ROA -53,00 yang diperoleh BPR Ayunulus tahun 2017 menunjukkan kuragnya rendahnya laba karena kurangnya tingkat pengembalian aset 1,2632. Nilai maksimum 8,00 diperoleh BPR Jero Anom tahun 2016 berarti bank tersebut telah mampu mengoptimalkan penerimaan laba bersih dari kegiatan yang dilakukan.

Nilai minimum dari BOPO adalah 49,00 diperoleh BPR Sedana Yasa tahun 2017 yang berarti bahwa BPR ini memiliki tingkat efisiensi tinggi terhadap biaya operasionalnya. Sedangkan nilai maksimum 570,00 oleh BPR Ayunulus tahun 2017 menunjukkan bahwa BPR ini kurang efisien dalam penggunaaan biaya operasionalnya. Rata-rata rasio BOPO 100,7719 menunjukkan masih banyak BPR yang kurang erfisien dalam mengelola biaya operaisonal karena melewati batas dari Bank Indonesia sebesar 96 persen. Nilai minimum dari LDR adalah 56,00 oleh BPR Ayunulus memperlihatkan bank memberikan kredit lebih kecil dari dana yang diperoleh. Rata-rata LDR adalah 82,0702 menunjukkan bank telah memberikan perhatian penuh pada likuiditasnya sehingga mampu berada di bawah batas yang ditetapkan Bank Indonesia sebesar 100 persen.

Uji multikoliniearitas digunakan untuk mengetahui apakah dalam model regresi terdapat hubungan antar variabel bebas. Dalam penelitian, model regresi yang memenuhi syarat adalah yang tidak memiliki hubungan dalam setiap 
variabel bebasnya. Hal ini dapat diketahui dengan melihat nilai tolerance dan VIF, seperti yang ditunjukkan pada tabel 5 .

Tabel 5.

Hasil Uji Multikoleniaritas

\begin{tabular}{lcll}
\hline \multicolumn{1}{c}{ Variabel } & Tolerance & VIF & \multicolumn{1}{c}{ Keterangan } \\
\hline CAR $\left(\mathrm{X}_{1}\right)$ & 0,584 & 1,712 & Bebas multikolinearitas \\
\hline NPL $\left(\mathrm{X}_{2}\right)$ & 0,537 & 1,862 & Bebas multikolinearitas \\
\hline PPAP $\left(\mathrm{X}_{3}\right)$ & 0,533 & 1,877 & Bebas multikolinearitas \\
\hline NPM $\left(\mathrm{X}_{4}\right)$ & 0,558 & 1,793 & Bebas multikolinearitas \\
\hline ROA $(\mathrm{X} 5)$ & 0,417 & 2,398 & Bebas multikolinearitas \\
\hline BOPO $(\mathrm{X} 6)$ & 0,340 & 2,942 & Bebas multikolinearitas \\
\hline LDR $(\mathrm{X} 7)$ & 0,394 & 2,540 & Bebas multikolinearitas \\
\hline
\end{tabular}

Sumber: Data diolah, 2019

Tabel 5. menunjukkan bahwa semua variabel bebas tidak mengandung multikolinearitas karena nilai VIF semua variabel kurang dari 10, dan nilai tolerance semua variabel lebih dari 0,1 , sehingga dapat disimpulkan bahwa model regresi layak uji dilihat dari segi multikoliniearitas.

Model penelitian diharapkan untuk tidak mengandung gejala autokorelasi karena adanya autokorelasi mengindikasikan bahwa terdapat penyimpangan dalam penelitian. Uji ini dilakukan dengan uji durbin-watson terhadap variabel yang menganggu model penelitian, yang ditunjukkan pada tabel 6.

Tabel 6.

Hasil Uji Autokorelasi

\begin{tabular}{crrrrr}
\hline Model & R & R Square & $\begin{array}{c}\text { Adjusted R } \\
\text { Square }\end{array}$ & $\begin{array}{c}\text { Std. Error of the } \\
\text { Estimate }\end{array}$ & Durbin-Watson \\
\hline 1 & $.960^{\mathrm{a}}$ & .922 & .911 & .09888 & 1.865 \\
\hline
\end{tabular}

Sumber: Data diolah, 2019

Uji autokorelasi dengan sampel berjumlah 57, jumlah variabel independen

7, dan taraf signifikan 5\% memperoleh nilai du sebesar 1,856. Jika dibandingkan 
dengan nilai batas atas (du) yaitu 1,856 kurang dari (4-du) 4-1,856=2,144, yang menunjukkan bahwa model bebas dari gejala autokorelasi.

Untuk menilai Keseluruhan Model (Overal Model Fit) pada analisis regresi logistik dapat dilakukan dengan cara menilai angka -2 log likelihood. Apabila terjadi penurunan angka $-2 \log$ likelihood dari awal (blok number $=0$ ) pada angka $-2 \log$ likelihood pada blok number $=1$, maka menunjukkan model regresi yang baik.

Tabel 7.

Overall Model Fit

\begin{tabular}{|c|c|c|c|c|c|}
\hline \multicolumn{6}{|c|}{$2 \log$ likelihood } \\
\hline \multicolumn{3}{|c|}{ blok number $=0$} & \multicolumn{3}{|c|}{ blok number $=1$} \\
\hline \multirow{20}{*}{ Step 0} & 1 & 43.902 & \multirow{20}{*}{ Step 1} & 1 & 16.305 \\
\hline & 2 & 42.488 & & 2 & 5.945 \\
\hline & 3 & 42.463 & & 3 & 2.277 \\
\hline & 4 & 42.463 & & 4 & .880 \\
\hline & 5 & 42.463 & & 5 & .339 \\
\hline & & & & 6 & .129 \\
\hline & & & & 7 & .049 \\
\hline & & & & 8 & .018 \\
\hline & & & & 9 & .007 \\
\hline & & & & 10 & .003 \\
\hline & & & & 11 & .001 \\
\hline & & & & 12 & .000 \\
\hline & & & & 13 & .000 \\
\hline & & & & 14 & .000 \\
\hline & & & & 15 & .000 \\
\hline & & & & 16 & .000 \\
\hline & & & & 17 & .000 \\
\hline & & & & 18 & .000 \\
\hline & & & & 19 & .000 \\
\hline & & & & 20 & .000 \\
\hline
\end{tabular}

Sumber: Data diolah, 2019

Hasil uji Keseluruhan Model (Overal Model Fit) pada Tabel 7. menunjukkan bahwa angka -2 log likelihood pada awal (blok number $=0$ ) dan -2 log likelihood pada blok number $=1$ mengalami penurunan, hal ini menunjukkan model regresi yang baik. Untuk menilai kelayakan model regresi pada uji regresi 
logistik penelitian ini digunakan Output dari Hosmer dan Lemeshow, dengan hipotesis berkut.

Ho : Model yang dihipotesiskan fit dengan data

Ha : Model yang dihipotesiskan tidak fit dengan data

Dasar pengambilan keputusan menggunakan nilai godness of fit test yang diukur dengan nilai chis square pada bagian bawah uji Hosmer dan Lemeshow. Apabila probabilitas $>0,05$ maka $\mathrm{H}_{0}$ diterima dan $\mathrm{Ha}$ ditolak, sebaliknya apabila probabilitas $<0,05$ maka $\mathrm{H}_{0}$ ditolak dan Ha diterima. Hasil uji Hosmer dan Lemeshow dapat dilihat pada Tabel 8.

Tabel 8.

Hasil Uji Hosmer dan Lemeshow

\begin{tabular}{|c|c|c|c|}
\hline \multicolumn{4}{|c|}{ Hosmer and Lemeshow Test } \\
\hline Step & Chi-square & $\mathrm{df}$ & Sig. \\
\hline 1 & .000 & 8 & 1.000 \\
\hline
\end{tabular}

Tabel hasil uji hosmer dan lemeshow menunjukkan nilai signifikansi 1,000. Nilai ini berada di atas 0,05 sehingga $\mathrm{H}_{0}$ diterima, yang berarti model penelitian layak digunakan.

Besarnya nilai koefisien determinasi ditunjukkan dengan nilai Nagelkerke $R$ Square pada model regeresi logistic. Hasil uji Nagelkerke $R$ Square dalam penelitian ini dapat dilihat pada tabel 9.

Tabel 9.

Hasil Uji Nagelkerke R Square

\begin{tabular}{cccc}
\hline Step & -2 Log likelihood & Cox \& Snell R Square & \multicolumn{2}{c}{ Nagelkerke R Square } \\
\hline 1 & $.000^{\mathrm{a}}$ & .525 & 1.000
\end{tabular}


a. Estimation terminated at iteration number 8 because parameter estimates changed by less than .001 .

Sumber: Data diolah, 2019

Tabel 9. menunjukkan nilai nilai Nagelkerke $R$ Square sebesar 1,000, yang menunjukkan bahwa variabel dalam penelitian yakni CAR, NPL, PPAP, NPM, ROA, BOPO dan LDR mempengaruhi keseluruhan probabilitas kondisi BPR yang bermasalah di Kabupaten Tabanan.

Uji simultan dilakukan untuk mengetahui ada tidaknya pengaruh variabel independen pada variabel bebas dengan menggunakan tingkat signifikansi 5 persen, yang ditunjukkan pada tabel 10 .

Tabel 10.

Omnibus Tests of Model Coefficients

\begin{tabular}{llrrr}
\hline & & Chi-square & df & \multicolumn{1}{c}{ Sig. } \\
\hline \multirow{3}{*}{ Step 1 } & Step & 42.463 & 7 & .000 \\
\cline { 2 - 5 } & Block & 42.463 & 7 & .000 \\
\cline { 2 - 5 } & Model & 42.463 & 7 & .000 \\
\hline
\end{tabular}

Sumber: Data diolah, 2019

Sesuai dengan tabel 10. nilai signifikansi sebesar 0,000 kurang dari 0,05 sebagai taraf signifikan yang digunakan, yang mennjukkan rasio CAR, PPAP, NPL, NPM, BOPO, ROA dan LDR memiliki kelayakan dalam mengukur probabilitas kondisi BPR yang bermasalah di Kabupaten Tabanan.

Tabel klasifikasi dipergunakan untuk mengamati ketepatan model probabilitas kondisi bermasalah, seperti yang dapat dilihat pada tabel 11.

\section{Tabel 11.}

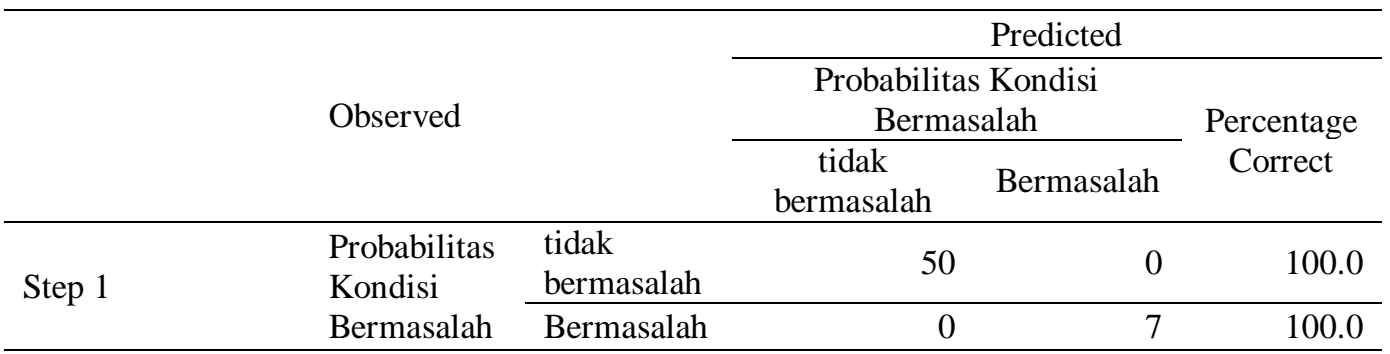




\begin{tabular}{lc}
\cline { 2 - 2 } Overall Percentage & 100.0 \\
\hline a. The cut value is .500 &
\end{tabular}

Sumber : Data diolah, 2019

\section{Klasifikasi}

Pada tabel 11. diketahui menurut observasi jumlah BPR pada kolom sesungguhnya sebanyak 50 bank tidak bermasalah dan 7 bank bermasalah. Sedangkan klasifikasi pada kolom prediksi terlihat bank yang tidak bermasalah sebanyak 50 dan bank bermasalah sebanyak 7 dengan ketepatan prediksi yang diamati untuk bank bermasalah dan tidak bermasalah adalah $100 \%$ dengan secara keseluruhan hasil klasifikasi menunjukan presentase ketepatan klasifikasi sebesar $100 \%$.

Regresi logistik uji Wald merupakan uji model penelitian untuk menentukan apakah variabel terikat memiliki pengaruh secara parsial dengan melihat nilai statistik wald dan Chi square pada nilai alpha 5\%. Hipotesis dinyatakan diterima atau variabel bebas secara parsial memiliki pengaruh apabila memperoleh nilai $p$ value kurang dari nlai alpha yang telah disebutkan sebelumnya. Hasil uji hipotesis dapat dilihat pada Tabel 12 .

Tabel 12.

Hasil Uji Wald

\begin{tabular}{lllccccr}
\hline \multicolumn{7}{c}{ Variables in the Equation } \\
\hline & \multicolumn{1}{c}{ B } & S.E. & Wald & df & Sig. & \multicolumn{1}{c}{ Exp(B) } \\
\hline \multirow{3}{*}{ ZCAR } & -1.408 & 6975.842 & 1.000 & 1 & .000 & .245 \\
\cline { 2 - 8 } & ZNPL & 3.528 & 10361.762 & 1.000 & 1 & .000 & 34.060 \\
\cline { 2 - 8 } & ZPPAP & 3.914 & 8880.994 & 1.000 & 1 & .000 & 50.077 \\
\cline { 2 - 8 } & ZNPM & -1.019 & 9795.572 & 1.000 & 1 & .000 & .361 \\
\cline { 2 - 8 } & ZROA & -5.267 & 20424.307 & 1.000 & 1 & .000 & .005 \\
\cline { 2 - 8 } & ZBOPO & 10.810 & 22158.229 & 1.000 & 1 & .000 & 49517.308 \\
\cline { 2 - 8 } & ZLDR & 1.020 & 3160.461 & 1.000 & 1 & .000 & 2.773 \\
\cline { 2 - 8 } & Constant & -22.036 & 7977.325 & .998 & 1 & .000 & .000
\end{tabular}

Sumber: Data diolah, 2019 
Berdasarkan hasil analisis pengaruh CAR terhadap probabilitas kondisi bermasalah BPR diperoleh nilai signifikasi uji wald sebesar 0,000. Nilai Signifikansi $0,000<0,050$ mengindikasikan bahwa $\mathrm{H}_{1}$ diterima. Hasil ini berarti bahwa CAR berpengaruh negatif dan signifikan terhadap probabilitas kondisi bermasalah BPR di Kabupaten Tabanan. Hasil analisis pengaruh NPL terhadap probabilitas kondisi bermasalah BPR diperoleh nilai signifikasi uji wald sebesar 0,000. Nilai Signifikansi $0,000<0,050$ mengindikasikan bahwa $\mathrm{H}_{2}$ diterima. Hasil ini berarti bahwa NPL berpengaruh positif dan signifikan terhadap probabilitas kondisi bermasalah BPR di Kabupaten Tabanan.

Hasil analisis pengaruh PPAP terhadap probabilitas kondisi bermasalah BPR diperoleh nilai signifikasi uji wald sebesar 0,000. Nilai Signifikansi 0,000< 0,050 mengindikasikan bahwa $\mathrm{H}_{3}$ diterima. Hasil ini berarti bahwa PPAP berpengaruh positif dan signifikan terhadap probabilitas kondisi bermasalah BPR di Kabupaten Tabanan. hasil analisis pengaruh NPM terhadap probabilitas kondisi bermasalah BPR diperoleh nilai signifikasi uji wald sebesar 0,000. Nilai Signifikansi $0,000<0,050$ mengindikasikan bahwa $\mathrm{H}_{4}$ diterima. Hasil ini berarti bahwa NPM berpengaruh negatif dan signifikan terhadap probabilitas kondisi bermasalah BPR di Kabupaten Tabanan.

Hasil analisis pengaruh ROA terhadap probabilitas kondisi bermasalah BPR diperoleh nilai signifikasi uji wald sebesar 0,000. Nilai Signifikansi 0,000<0,050 mengindikasikan bahwa $\mathrm{H}_{5}$ diterima. Hasil ini berarti bahwa ROA berpengaruh negatif dan signifikan terhadap probabilitas kondisi bermasalah BPR di Kabupaten Tabanan. hasil analisis pengaruh BOPO terhadap probabilitas kondisi bermasalah BPR diperoleh nilai signifikasi uji wald sebesar 0,000. Nilai 
Signifikansi $0,000<0,050$ mengindikasikan bahwa $\mathrm{H}_{6}$ diterima. Hasil ini berarti bahwa BOPO berpengaruh positif dan signifikan terhadap probabilitas kondisi bermasalah BPR di Kabupaten Tabanan. hasil analisis pengaruh LDR terhadap probabilitas kondisi bermasalah BPR diperoleh nilai signifikasi uji wald sebesar 0,000. Nilai Signifikansi 0,000 $<0,050$ mengindikasikan bahwa $\mathrm{H}_{7}$ diterima. Hasil ini berarti bahwa LDR berpengaruh positif dan signifikan terhadap probabilitas kondisi bermasalah BPR di Kabupaten Tabanan.

Model regresi logistik yang terbentuk sebagai hasil dari uji penelitian ini dapat dilihat pada tabel 13. berikut.

Tabel 13.

Model Regresi Terbentuk

\begin{tabular}{|c|c|c|c|c|c|c|c|}
\hline & & B & S.E. & Wald & df & Sig. & $\operatorname{Exp}(B)$ \\
\hline \multirow{9}{*}{ Step $1^{\mathrm{a}}$} & ZCAR & -1.408 & 6975.842 & 1.000 & 1 & .000 & .245 \\
\hline & ZNPL & 3.528 & 10361.762 & 1.000 & 1 & .000 & 34.060 \\
\hline & ZPPAP & 3.914 & 8880.994 & 1.000 & 1 & .000 & 50.077 \\
\hline & ZNPM & -1.019 & 9795.572 & 1.000 & 1 & .000 & .361 \\
\hline & ZROA & -5.267 & 20424.307 & 1.000 & 1 & .000 & .005 \\
\hline & & B & S.E. & Wald & df & Sig. & $\operatorname{Exp}(B)$ \\
\hline & ZBOPO & 10.810 & 22158.229 & 1.000 & 1 & .000 & 49517.308 \\
\hline & ZLDR & 1.020 & 3160.461 & 1.000 & 1 & .000 & 2.773 \\
\hline & Constant & -22.036 & 7977.325 & .998 & 1 & .000 & .000 \\
\hline
\end{tabular}

Sumber: Data diolah, 2019

Konstanta bernilai -22,036 menunjukkan apabila semua variabel bernilai nol, maka kemungkinan bank bermasalah akan bernilai -22,036. Nilai koefisien CAR sebesar 1,408 menunjukkan bila CAR meningkat 1 satuan, maka terjadi penurunan kondisi bermasalah bank 1,408. Hal ini berlaku juga pada koefisien variabel yang bernilai negatif seperti NPM, apabila terjadi peningkatan NPM 
sebesar 1 satuan sedangkan variabel lain dianggap konstan, maka akan menurunkan probabilitas kondisi bermasalah bank sebesar -1,019 dan ROA, apabila terjadi peningkatan ROA sebesar 1 satuan sedangkan variabel lain dianggap konstan, maka akan menurunkan probabilitas kondisi bermasalah bank sebesar -5,267. Nilai koefisien NPL 3,528 menunjukkan apabila NPL naik sebesar 1 satuan, maka meningkatkan kemungkinan kondisi bermasalah sebesar 3,528, dan berlaku pada koefisien variabel yang bernilai positif lainnya seperti PPAP, apabila terjadi peningkatan PPAP sebesar 1 satuan sedangkan variabel lain dianggap konstan, maka akan menaikan probabilitas kondisi bermasalah bank sebesar 3,914, BOPO, apabila terjadi peningkatan BOPO sebesar 1 satuan sedangkan variabel lain dianggap konstan, maka akan menaikan probabilitas kondisi bermasalah bank sebesar 10,810 dan LDR, apabila terjadi peningkatan LDR sebesar 1 satuan sedangkan variabel lain dianggap konstan, maka akan menaikan probabilitas kondisi bermasalah bank sebesar 1,020.

\section{SIMPULAN}

Berdasarkan hasil penelitian yang telah dilakukan di Bank Perkreditan Rakyat di Kabupaten Tabanan pada periode tahun 2015 sampai 2017, maka dapat disimpulkan bahwa rasio CAR, NPM, dan ROA berpengaruh negatif pada probabilitas kondisi bermasalah BPR di Kabupaten Tabanan, yang berarti semakin tinggi CAR, NPM, dan ROA maka probabilitas bank mengalami kondisi bermasalah akan semakin kecil. Sedangkan rasio NPL, PPAP, BOPO, dan LDR brpengaruh positif pada probabilitas kondisi bermasalah BPR di Kabupaten Tabanan, yang berarti semakin tinggi NPL, PPAP, BOPO, dan LDR maka probabilitas bank mengalami kondisi bermasalah akan semakin besar. Hasil 
penelitian menyumbangkan tambahan informasi secara empiris mengenai manajemen risiko dimana variabel yang digunakan meliputi CAR, NPL, PPAP, NPM, ROA, BOPO, LDR memiliki pengaruh signifikan terhadap probabilitas kondisi bermasalah. Ini menunjukkan bahwa manajemen risiko bisa dinilai dari variabel-variabel meliputi CAR, NPL, PPAP, NPM, ROA, BOPO, LDR. Perusahaan khususnya bank baik bank umum maupun BPR harus memperhatikan rasio-rasio meliputi CAR, NPL, PPAP, NPM, ROA, BOPO, LDR untuk menilai kondisi kesehatan bank. penelitian ini dapat dapat dijadikan sebagai bahan masukan dan juga informasi bagi calon nasabah yang akan menggunakan jasa perbankan dalam menyimpan, meminjam maupun untuk mendepositokan uangnya dengan mempertimbangkan kinerja dari bank tersebut dan dapat dijadikan bahan referensi bahwa penting halnya untuk mengetahui kondisi bank mana yang memiliki kondisi baik agar dana yang disimpan tetap aman.

\section{REFERENSI}

Armanto, B. (2016). Tahun Depan, OJK Perketat Tata Kelola BPR.

Culata, P. R. E., \& Gunarsih, T. (2012). Pecking Order Theory and Trade-Off Theory of Capital Structure: Evidence from Indonesian Stock Exchange. Journal The Winners, 13(1), 40-49. https://doi.org/10.21512/tw.v13i1.666

Ebrahimi, S. K., Bahraminasab, A., \& Seyedi, F. S. (2017). The Impact of CAMEL Indexes on Profit Management in Banks Listed on Tehran Stock Exchange. International Review of Management and Marketing, 7(2), 421429. Retrieved from http://indiraisbs.ac.in/IMR/wpcontent/uploads/2017/11/Vijay-Hemant-Sonaje-and-Dr.-Shriram-S.Nerlekar.pdf

Hadad, M. D., Santoso, W., \& Sarweh. (2017). Model Prediksi Kepailitan Bank Umum di Indonesia.

Harjanti, R. S. (2011). Analisis Pengaruh Rasio Keuangan Terhadap Kinerja Bank. Skripsi. Sarjana Akuntansi Fakultas Ekonomi Universitas Diponegoro. 
Ismawati, K., \& Istria, P. C. (2015). Detektor Financial Distress Perusahaan Perbankan Indonesia. Ekonomi Bisnis \& Kewirausahaan, 4(1), 6-29.

Jaouad, E., \& Lahsen, O. (2018). Factors Affecting Bank Performance: Empirical Evidence from Morocco. European Scientific Journal ESJ, 14(34), 255-267. https://doi.org/10.19044/esj.2018.v14n34p255

Jurnali, T. (2010). Manfaat Rasio Keuangan Dalam Memprediksi Kepailitan Bank Nasional. Jurnal Bisnis Dan Akuntansi, 12(1), 39-52.

Khoury, E., \& Salem, C. G. (2018). Ranking and Rating Lebanese Commercial Banks: A CAMELS Framework. International Academic Journal of Accounting and Financial Management, 5(4), 49-65. Retrieved from www.iaiest.com

Kokobe, S., \& Gemechu, D. (2016). Risk Management Techniques and Financial Performance of Insurance Companies. International Journal of Accounting Research, 4(1), 1-5. https://doi.org/10.4172/2472-114x.1000127

Lakada, M. N., Lapian, S. I. H. V. ., \& Tumiwa, J. R. (2017). Analyzing The Financial Statement Using Horizontal-Vertical Analysis to Evaluating The Company Financial Performance Period 2012-2016 (Case Study at PT. Unilever Indonesia Tbk). Jurnal EMBA: Jurnal Riset Ekonomi, Manajemen, Bisnis Dan Akuntansi, 5(3), 3985-3994.

Latumaerissa, J. R. (2011). Bank dan Lembaga Keuangan Lain. Jakarta: Salemba Empat.

Lianawati, N., Rahayu, S. M., \& Nuzula, N. F. (2016). Penilaian Kesehatan Bank Perkreditan Rakyat (Bpr) Berdasarkan Surat Keputusan Direksi Bank Indonesia No 30/12/Kep/Dir Tahun 1997. Jurnal Administrasi Bisnis, 30(1), $125-134$.

Majumder, M. T. H., \& Rahman, M. M. (2016). A CAMEL Model Analysis of Selected Banks in Bangladesh. International Journal of Business and Technopreneurship, 6(2), 233-266. https://doi.org/10.2139/ssrn.3068004

Martharini, L. (2010). Analisis Pengaruh Rasio CAMEL dan Size terhadap Prediksi Kondisi Bermasalah pada Perbankan. Skripsi. Sarjana Akuntansi Fakultas Ekonomi dan Bisnis Universitas Diponegoro.

Myšková, R., \& Hájek, P. (2018). Comprehensive assessment of firm financial performance using financial ratios and linguistic analysis of annual reports. Journal of International Studies, 10(4), 96-108. https://doi.org/10.14254/2071-8330.2017/10-4/7

Nugroho, A. (2011). Analisis Pengaruh Rasio CAR, NPL, ROA, BOPO, dan LDR terhadap Prediksi Kondisi Bermasalah Usaha Perbankan di Indonesia Versi Majalah Infobank. Skripsi. Sarjana Akuntansi Fakultas Ekonomi Universitas Diponegoro. 
Ojo, A. S., Enekwe, C. I., Wanted, M., Terms, F., Important, M., Ratios, F., ... See, R. (2015). Corporate Profitability: a Study of Selected Quoted Oil and. Canadian Social Science, 3(1), 17-34.

Rahman, M. Z., \& Islam, M. S. (2017). Use of CAMEL Rating Framework: A Comparative Performance Evaluation of Selected Bangladeshi Private Commercial Banks. International Journal of Economics and Finance, 10(1), 120. https://doi.org/10.5539/ijef.v10n1p120

Rahmania, M. F., \& Hermanto, S. B. (2014). Analisis Rasio Keuangan Terhadap Financial Distress Perusahaan Perbankan Studi Empiris Di Bei 2010-2012. Jurnal Ilmu \& Riset Akuntansi, 3(11), 1-20.

Rashid, C. A. (2018). Efficiency of Financial Ratios Analysis for Evaluating Companies' Liquidity. International Journal of Social Sciences \& Educational Studies, 4(4), 110-123. https://doi.org/10.23918/ijsses.v4i4p110

Saiya, S. I. J., \& Pandowo, M. (2015). Analysis of banking soundness using camel method. Jurnal EMBA, 3(2), 132-140.

Sethi, N., Sahoo, K., \& Sucharita, S. (2013). a Survey of International Financial Risk Management System. Journal of Public Administration, Finance and Law, (4), 186-203.

Sofiasani, G., \& Gautama, B. P. (2016). Pengaruh CAMEL Terhadap Financial Distress Pada Sektor Perbankan Indonesia Periode 2009-2013. Journal of Business Management and Enterpreneurship Education, 1(1), 136-146.

Sonaje, V. H., \& Nerlekar, S. S. (2017). Financial Performance Analysis of Selected Banks Using CAMEL Approach. Indira Management Review, 11(2), 17-24. Retrieved from http://indiraisbs.ac.in/IMR/wpcontent/uploads/2017/11/Vijay-Hemant-Sonaje-and-Dr.-Shriram-S.Nerlekar.pdf

Tilehnouei, M. H., \& Shivaraj, B. (2014). A Brief Review of Capital Structure Theories. Research Journal of Recent Sciences, 3(10), 113-118.

Tursoy, T. (2018). Risk Management Process in Banking Industry. Munich Personal RePEc Archive.

Wiagustini, N. L. P., Ramantha, I. W., Panji Sedana, I. B., \& Rahyuda, H. (2017). Indonesia's capital structure: Pecking order theory or trade-off theory. International Journal of Applied Business and Economic Research, 15(16), $119-131$.

Wicaksana, R. L. (2011). Analisis Pengaruh Rasio CAMEL Terhadap Kondisi Bermasalah Pada Sektor Perbankan Di Indonesia. E-Jurnal Universitas Diponegoro. Skripsi. Sarjana Akuntansi Fakultas Ekonomi dan Bisnis Universitas Diponegoro. 
Nyoman Ariyoga Nuryadiputra. Pengaruh Rasio Keuangan Camel Terhadap Kondisi.

Zaki, E., Bah, R., \& Rao, A. (2011). Assessing probabilities of financial distress of banks in UAE. International Journal of Managerial Finance, 7(3), 304320. https://doi.org/10.1108/17439131111144487 